\title{
Efficacies of Various Anaerobic Starter Seeds for Biogas Production from Different Types of Wastewater
}

\author{
Pawinee Chaiprasert, ${ }^{1}$ Nasrul Hudayah, ${ }^{2}$ and Chompoonut Auphimai ${ }^{1}$ \\ ${ }^{1}$ Biotechnology Program, School of Bioresources and Technology, King Mongkut's University of Technology Thonburi, Bangkhunthian, \\ Bangkok 10150, Thailand \\ ${ }^{2}$ ECoWaste, The Joint Graduate School of Energy and Environment, King Mongkut's University of Technology Thonburi, Thungkru, \\ Bangkok 10140, Thailand \\ Correspondence should be addressed to Pawinee Chaiprasert; pawinee.cha@kmutt.ac.th
}

Received 30 May 2017; Revised 13 July 2017; Accepted 24 July 2017; Published 28 August 2017

Academic Editor: Pengjun Shi

Copyright (C) 2017 Pawinee Chaiprasert et al. This is an open access article distributed under the Creative Commons Attribution License, which permits unrestricted use, distribution, and reproduction in any medium, provided the original work is properly cited.

\begin{abstract}
Various anaerobic starter seeds from different sources were investigated for their efficacies in treatment of different types of wastewater. Six combinations of starter seeds and wastewaters were selected out of 25 combination batch experiments and operated in semicontinuous reactors. It was noticed that the efficacies of various anaerobic starter seeds for biogas production from different types of wastewater in terms of reactor performance and stability were depended on wastewater characteristics and F/M ratio affecting microbial community and their microbial activities. However, exogenous starter seed can be used across different types of wastewater with or without acclimatization. Four reactors reached the targeted OLR of $2 \mathrm{~kg} \mathrm{COD} / \mathrm{m}^{3} \cdot \mathrm{d}$ with high performance and stability except for concentrated rubber wastewater (RBw), even using high active starter seeds of cassava starch (CSs) and palm oil (POs). The toxic compounds in RBw such as ammonia and sulfate might also adversely affect methanogenic activity in CSsRBw and POsRBw reactors. DGGE analysis showed that propionate utilizers, Smithella propionica strain LYP and Syntrophus sp., were detected in all samples. For Archaea domain, methylotrophic, hydrogenotrophic, and acetoclastic methanogens were also detected. Syntrophic relationships were assumed between propionate utilizers and methanogens as acetate/H2 producers and utilizers, respectively.
\end{abstract}

\section{Introduction}

Alternative energy generation options, which are economic well-being with green future, are demanded to accomplish global energy demand and environmental concerns [1]. Production of bioenergy has shown an impressive growth concerning energy demands with sustainable perspectives. Anaerobic digestion gains its popularity for organic wastewater treatment because it proves an excellent biological process for waste stabilization by both recovering on energy and compost. It also offers simple and compact technology with high COD removal efficiencies and low sludge production which lead to economical and feasible application in industrial scale of wastewater treatment. Methane, as a main product in anaerobic digestion, was able to generate approximately $1.5 \mathrm{kWh}$ electric energy per kg COD removed with assumption of $40 \%$ electric conversion efficiency from methane [2]. Therefore, anaerobic digestion is considered as the most appropriate method to treat organic wastewaters, such as food processing and agricultural based industries.

In Thailand, wastewaters from agricultural based industries are main sources for biogas production [3]. These wastewaters had different characteristics which affected the operational design of anaerobic digestion system. Start-up strategy, one of operational parameters in anaerobic reactor, must be considered in order to operate anaerobic reactor with good stability for long period. Poor start-up can cause longer acclimation of microorganism to wastewater which then leads to inefficient organic removals or reactor fail [4]. Start-up of anaerobic reactor is commonly affected by several parameters such as reactor configuration, wastewater characteristics, environmental conditions, and microbial starter 
seeds [5]. Selection of appropriate microbial starter seeds is considered as critical factor to assure the good performance of anaerobic reactor $[6,7]$.

For starting up anaerobic reactor, anaerobic sludge or granule from another reactor is commonly used and inoculated to new anaerobic reactor for the reasons of its high microbial activity and congeniality [5, 8]. However, the limitation on its availability is a main drawback for starting up anaerobic reactor. Providing an alternative or exogenous starter seed which has good microbial activity and is easy or available nearby the wastewater treatment plant is considered. Selection for new starter seeds must be focused only not on the quantity of its source and amount, but also on the quality of it, such as microbial activity and community [5]. In this study, microbial starter seeds from 5 different wastewater treatment plants, for example, cassava starch (high carbohydrates), palm oil mill (high oil and grease), soymilk processing (high protein), concentrated rubber (high protein), and swine manure (high nitrogen and lignocellulosic matter) wastewater treatment plants, will be investigated for their suitability as exogenous starter seeds or inoculum. This study was aimed to investigate the efficacies of exogenous microbial starter seeds, in terms of microbial activity and performance, to treat different wastewater types. Therefore, the results of this study were expected to contribute on the knowledge and critical parameters for starting up new anaerobic reactor by using exogenous microbial starter seeds.

\section{Materials and Methods}

2.1. Starter Seeds. The starter seeds were collected from fullscale anaerobic reactors which were operated more than 5 years with normal organic loading rate and high efficiency (more than 75\% COD removal) under ambient temperature of $30-35^{\circ} \mathrm{C}$. Five anaerobic starter seeds used in this study were (1) rubber starter seed (RBs) which was collected from anaerobic wastewater treatment plant (WWTP) of concentrated rubber factory; (2) cassava starch seed (CSs) which was collected from anaerobic covered lagoon of WWTP at cassava starch factory; (3) palm oil starter seed (POs) which was collected from anaerobic WWTP treating POME at palm oil factory; (4) swine starter seed (SWs) which was collected from swine manure WWTP at local farm; (5) soymilk starter seed (SMs) which was collected from anaerobic pond WWTP at soy milk processing factory. These starter seeds were characterized for their biomass characteristics, for example, volatile suspended solids (VSS) and total suspended solids (TSS), specific glucose utilization (SGU), specific methanogenic activity (SMA), and microbial community.

2.2. Wastewater Characteristics. 5 different wastewaters were also used in this study such as wastewater of concentrated rubber $(\mathrm{RBw})$, cassava starch $(\mathrm{CSw})$, palm oil mill effluent $(\mathrm{POw})$, swine manure ( $\mathrm{SWw})$, and soymilk processing $(\mathrm{SMw})$. These wastewaters were collected from the same factory as the starter seeds. The characteristics of these wastewaters are shown in Table 1.

2.3. Experimental Design. A factorial experiment was designed for two variables of starter seeds and wastewaters. 5 different starter seeds and wastewaters were carried out in a $5 \times 5$ factorial experiment design as shown in Table 2 . These 25 experiments were conducted in $120 \mathrm{~mL}$ serum vials with working volume of $100 \mathrm{~mL}$. Food to microorganism (F/M) ratio of 0.3 was used with COD and VSS concentration of 2 and $6 \mathrm{~g} / \mathrm{L}$, respectively. To control initial COD concentration at $2 \mathrm{~g} / \mathrm{L}$, the wastewaters were adjusted with basal medium which consisted of $(\mathrm{NH})_{2} \mathrm{SO}_{4} 132 \mathrm{mg} / \mathrm{L}, \mathrm{NaH}_{2} \mathrm{PO}_{4} \cdot \mathrm{H}_{2} \mathrm{O}$ $75.5 \mathrm{mg} / \mathrm{L}, \mathrm{CaCl}_{2} \cdot 2 \mathrm{H}_{2} \mathrm{O} 50 \mathrm{mg} / \mathrm{L}, \mathrm{MgSO}_{4} \cdot 7 \mathrm{H}_{2} \mathrm{O} 90 \mathrm{mg} / \mathrm{L}$, yeast extracts $10 \mathrm{mg} / \mathrm{L}$, and nutrient solution $0.3 \mathrm{~mL} / \mathrm{L}$. Nitrogen gas was used to flush vial headspace prior to be closed and sealed with rubber and aluminium caps and then incubated at $37^{\circ} \mathrm{C}$. Biogas production and composition were analyzed three times per week until constant biogas accumulation. $\mathrm{CH}_{4}$ production rate was calculated by dividing methane production $(\mathrm{mL})$ by the time of maximum methane production (day), while $\mathrm{CH}_{4}$ yield was calculated by dividing cumulative $\mathrm{CH}_{4}$ volume $(\mathrm{mL})$ with initial $\mathrm{COD}_{\text {added }}$.

Only six combinations between different starter seeds and wastewaters were selected from 25 factorial experiment design based on the result of maximum $\mathrm{CH}_{4}$ production time for further step. Those experiments were conducted in a glass digester with working volume of $1 \mathrm{~L} .5 \mathrm{~g}$ VSS/L of starter seed was inoculated in these digesters and organic loading rate (OLR) was stepwise increased from 0.5 to $2.0 \mathrm{~kg} \mathrm{COD} / \mathrm{m}^{3} \cdot \mathrm{d}$ during start-up period based on the COD concentration of wastewaters. The digesters were semicontinuously operated at HRT of 5 days under ambient temperature. Digester performances, such as COD removal, $\mathrm{pH}$, TVA/alkalinity, and $\mathrm{CH}_{4}$ production, were investigated. Microbial activity and community were also analyzed at the end of start-up period.

\subsection{Analytical Methods}

2.4.1. Wastewater Characteristics. All raw wastewaters were stored at $4^{\circ} \mathrm{C}$ before being used in this study. The characteristics of wastewaters, such as $\mathrm{pH}$, alkalinity, TVA, COD, TS, VS, ash, oil and grease, TKN, and protein, were analyzed based on APHA Standard Methods [9]. The carbohydrate concentration was determined by difference between 100 and sum of the percentages of moisture, crude protein, lipid, and ash [10].

2.4.2. Reactor Performance. $\mathrm{pH}$, alkalinity, and TVA were analyzed daily according to standard method [9]. Soluble and total COD were analyzed every 2 days. Biomass concentration, VSS, and TSS were analyzed at initial and final of treatment [9]. Biogas production was analyzed by water replacement method and its composition was analyzed by gas chromatography (GC) 14B with thermal conductivity detector (Shimadzu, Japan). 
TABLE 1: The characteristics of various wastewaters used in this study.

\begin{tabular}{|c|c|c|c|c|c|c|}
\hline Parameter & Unit & $\mathrm{RBw}$ & CSw & POw & SWw & SMw \\
\hline $\mathrm{pH}$ & - & 4.58 & 4.58 & 4.26 & 7.24 & 4.06 \\
\hline Alkalinity & $\mathrm{mg} / \mathrm{L}$ & 1,100 & 400 & 1,100 & 13,000 & 400 \\
\hline Total volatile acid (TVA) & $\mathrm{mg} / \mathrm{L}$ & 3,460 & 1,100 & 6,117 & 11,000 & 100 \\
\hline Total COD (TCOD) & $\mathrm{mg} / \mathrm{L}$ & 17,200 & 25,200 & 86,200 & 181,100 & 7,300 \\
\hline Soluble COD (SCOD) & $\mathrm{mg} / \mathrm{L}$ & 16,900 & 14,200 & 45,000 & 19,100 & 3,000 \\
\hline Total Kjeldahl nitrogen (TKN) & $\mathrm{mg} / \mathrm{L}$ & 1,800 & 400 & 1,100 & 6,500 & 300 \\
\hline Total solids (TS) & $\mathrm{g} / \mathrm{L}$ & 16.40 & 19.37 & 60.05 & 188.20 & 4.67 \\
\hline Volatile solids (VS) & $\mathrm{g} / \mathrm{L}$ & 13.82 & 16.91 & 50.24 & 146.9 & 4.09 \\
\hline Protein $(\mathrm{P})$ & $\mathrm{g} / \mathrm{L}$ & 10.98 & 2.30 & 6.78 & 40.47 & 1.55 \\
\hline Carbohydrate (C) & $\mathrm{g} / \mathrm{L}$ & 2.84 & 13.97 & 29.89 & 81.30 & 1.73 \\
\hline Oil \& grease $(\mathrm{O})$ & $\mathrm{g} / \mathrm{L}$ & 0 & 0.63 & 13.56 & 16.10 & 0.82 \\
\hline $\mathrm{P}: \mathrm{C}: \mathrm{O}$ ratio & - & $4: 1: 0$ & $4: 22: 1$ & $1: 4: 2$ & $3: 5: 1$ & $2: 2: 1$ \\
\hline
\end{tabular}

TABLE 2: $5 \times 5$ factorial experiment design of starter seeds and wastewaters.

\begin{tabular}{|c|c|c|}
\hline Starter seed & Wastewater & Abbreviation \\
\hline \multirow{5}{*}{ Concentrated rubber (RBs) } & Concentrated rubber $(\mathrm{RBw})$ & RBsRBw \\
\hline & Cassava starch $(\mathrm{CSw})$ & $\mathrm{RBsCSw}$ \\
\hline & Palm oil mill (POw) & RBsPOw \\
\hline & Swine manure (SWw) & RBsSWw \\
\hline & Soymilk processing (SMw) & $\mathrm{RBsSMw}$ \\
\hline \multirow{5}{*}{ Cassava starch (CSs) } & Concentrated rubber (RBw) & CSsRBw \\
\hline & Cassava starch $(\mathrm{CSw})$ & $\mathrm{CSsCSw}$ \\
\hline & Palm oil mill (POw) & CSsPOw \\
\hline & Swine manure (SWw) & CSsSWw \\
\hline & Soymilk processing (SMw) & CSsSMw \\
\hline \multirow{5}{*}{ Palm oil mill (POs) } & Concentrated rubber $(\mathrm{RBw})$ & POsRBw \\
\hline & Cassava starch (CSw) & POsCSw \\
\hline & Palm oil mill (POw) & POsPOw \\
\hline & Swine manure (SWw) & POsSWw \\
\hline & Soymilk processing (SMw) & POsSMw \\
\hline \multirow{5}{*}{ Swine manure (SWs) } & Concentrated rubber (RBw) & SWsRBw \\
\hline & Cassava starch $(\mathrm{CSw})$ & SWsCSw \\
\hline & Palm oil mill (POw) & SWsPOw \\
\hline & Swine manure (SWw) & SWsSWw \\
\hline & Soymilk processing (SMw) & SWsSMw \\
\hline \multirow{5}{*}{ Soymilk processing (SMs) } & Concentrated rubber (RBw) & SMsRBw \\
\hline & Cassava starch $(\mathrm{CSw})$ & SMsCSw \\
\hline & Palm oil mill (POw) & SMsPOw \\
\hline & Swine manure (SWw) & SMsSWw \\
\hline & Soymilk processing (SMw) & SMsSMw \\
\hline
\end{tabular}

2.4.3. Microbial Activity. Specific glucose utilization (SGU) represented the activity of starter seed to degrade glucose. $3 \mathrm{~g} \mathrm{VSS} / \mathrm{L}$ of starter seed was inoculated in $120 \mathrm{~mL}$ serum vial with glucose $(1 \mathrm{~g} / \mathrm{L})$ as main substrate to achieve $\mathrm{F} / \mathrm{M}$ ratio of $0.3 . \mathrm{N}_{2}$ gas (99.99\%) was flushed to vial headspace to remove oxygen prior to be closed and sealed with rubber and aluminium caps. The vial was incubated in $37^{\circ} \mathrm{C}$ incubator. Sampling was conducted every 2 hours for 24 hours and glucose concentration was analyzed by dinitrosalicylic acid
(DNS) method [11]. Maximum slope of glucose degradation was calculated as maximum SGU activity. SGU was expressed as an amount of COD-glucose which was degraded by onegram VSS of microorganism per hour (g COD-glucose/g VSS.h).

Specific methanogenic assay (SMA) represented the activity of acetoclastic methanogen in sample [12]. Sodium acetate of $1 \mathrm{~g} / \mathrm{L}$ was used as main substrate. $3 \mathrm{~g}$ VSS/L was also inoculated into $120 \mathrm{~mL}$ serum vial for $\mathrm{F} / \mathrm{M}$ ratio of 
0.3. $\mathrm{N}_{2}$ gas was flushed for vial headspace. The vial will be incubated under $37^{\circ} \mathrm{C}$. Biogas production and composition, as a result from acetate degradation, were daily analyzed until constant accumulation of biogas production. Maximum slope of methane production was considered as SMA value in which $\mathrm{mL} \mathrm{CH}_{4}$ was converted as $\mathrm{g} \mathrm{COD}-\mathrm{CH}_{4}$. SMA value was defined as amount of $\mathrm{g}$ COD which was degraded by onegram VSS of microorganism per day (g COD- $\mathrm{CH}_{4} / \mathrm{g}$ VSS·d).

2.4.4. Microbial Community. Total genomic DNA was extracted from samples according to the method of [13]. The bacterial 16S rRNA gene was amplified by PCR with the bacterial primer EUB8F and U1492R in the first round and the specific primer set 338GC-F and 518R in the second round [14]. The archaeal $16 \mathrm{~S}$ rRNA gene was amplified by PCR with the archaeal primer A20F and U1492R in the first round and the specific primer set $344 \mathrm{GC}-\mathrm{F} / 522 \mathrm{R}$ in the second round $[14,15]$.

The 200 bp PCR fragments were analyzed by DGGE on the DGGE-2000 system apparatus (CBS Scientific Co. Inc., USA). The equal volumes of PCR products were run on a DGGE with $8 \%$ polyacrylamide gels in $1 x$ TAE (Tris-acetateEDTA) buffer. The gradients were created by the addition of $0-80 \%$ denaturant (5.6 $\mathrm{M}$ urea and $40 \% \mathrm{v} / \mathrm{v}$ formamide) into polyacrylamide [16]. A 45-70\% denaturing gradient was used for the domain of Eubacteria, while 40-55\% denaturing gradient was used for the domain of Archaea. Electrophoresis was performed at $200 \mathrm{~V}$ for $5 \mathrm{~h}$ and at a constant temperature of $60^{\circ} \mathrm{C}$. After electrophoresis, the gels were stained with SYBR Gold nucleic acid stain (Molecular Probes, USA) for 15 minutes. The image was then visualized on UV transilluminator and was captured using Biovision CN 1000/26 M (Vilber Lourmat, France).

Most of the bands were excised from the gel by using Gel Cutting Tips (Cleaver Scientific, England) and reamplified with the primer 338GC-F/518R and 344GC-F/522R for the domain of Eubacteria and Archaea, respectively. The PCR products were purified using the Gel/PCR DNA fragments extraction kit (Geneaid, Taiwan) according to the manufacturer's instruction. The purified PCR products were sequenced using the 1st BASE Laboratories Sdn Bhd (Malaysia). Sequences were initially compared to known $16 S$ rRNA sequences in the GenBank ${ }^{\mathrm{TM}}$ database using the BLAST to locate nearly exact matches in the GenBank database [17].

\section{Results and Discussion}

3.1. Selection for Efficient Combination of Exogenous Starter Seed and Various Wastewaters. Lag time for $\mathrm{CH}_{4}$ production, $\mathrm{CH}_{4}$ production rate, and ultimate $\mathrm{CH}_{4}$ production time were considered as main selection parameters. Table 3 shows that each experiment of combination starter seeds and wastewater was able to produce $\mathrm{CH}_{4}$ with different lag time and production rate. The combination between wastewater from swine farm $(\mathrm{SWw})$ and various starter seeds showed the slowest ultimate $\mathrm{CH}_{4}$ production time and rate. sCOD/tCOD ratio of SWw was the lowest, approximately $11 \%$, compared to $\mathrm{RBw}, \mathrm{CSw}$, Pow, and SMw as approximately 98, 56, 51, and $41 \%$, respectively (Table 2 ). Low $\mathrm{sCOD} / \mathrm{tCOD}$ ratio indicated high insoluble particles and solids fractions which was difficult to be degraded by microorganism. Contrary, highest sCOD/tCOD ratio in $\mathrm{RBw}$ resulted in higher $\mathrm{CH}_{4}$ production rates as approximately $12.37,8.95,8.32,7.08$, and $5.91 \mathrm{~mL} \mathrm{CH} / \mathrm{g} \cdot \mathrm{VSS} \cdot \mathrm{d}$ with starter seed combinations of CSs, POs, SWs, SMs, and RBs, respectively.

Initial SMA of starter seeds also affected microbial activity to degrade different wastewater characteristics. Based on preliminary results, SMA values of SWs, POs, CSs, SMs, and RBs were approximately $0.11,0.10,0.09,0.07$, and $0.01 \mathrm{~g}$ COD$\mathrm{CH}_{4} / \mathrm{g}$ VSS.d, respectively. RBs had the lowest SMA value which affected its performance on wastewater degradation. In the easiest degradable and indigenous concentrated rubber wastewater (RBw), RBs also showed the lowest ultimate $\mathrm{CH}_{4}$ production times and rates compared to that of another starter seeds. $\mathrm{RBs}$ had longer lag phase for $\mathrm{CH}_{4}$ production, approximately 5-10 days, which indicated that microorganism in this starter seed needed time to adapt on different wastewaters due to its low activity. The fastest or highest of $\mathrm{CH}_{4}$ production slopes were observed in wastewaters combination with SWs and CSs followed by POs, SMs, and RBs.

The efficacies of 5 different various starter seeds with different wastewaters considering ultimate $\mathrm{CH}_{4}$ production time, rate, and lag time are shown in Table $3 . \mathrm{CH}_{4}$ production rates varied between 1.71 and $12.37 \mathrm{~mL} \mathrm{CH}_{4} / \mathrm{g}$ VSS.d, in which most RBw combination showed highest ultimate $\mathrm{CH}_{4}$ production times and rates. These parameters were important for determining the application of starter seed and wastewater combinations in next step with stepwise increase of OLR operation. The fastest ultimate $\mathrm{CH}_{4}$ production time in each representative starter seeds were selected. Six conditions of combinations starter seed and wastewater were selected for next phase regarding on ultimate $\mathrm{CH}_{4}$ production time in order to deeply observation the efficacies of starter seed application for exogenous wastewaters. Combinations of CSsRBw, POsRBw, SMsPOw, RBsSWw, and SWsCSw were selected based on ultimate $\mathrm{CH}_{4}$ production time for CSs, POs, SMs, RBs, and SWs, respectively, while CSsSWw was also selected concerning on ultimate $\mathrm{CH}_{4}$ production time for combination using swine wastewater (SWw).

\subsection{Application of Selected Combination of Different Starter} Seeds and Wastewater for Start-Up Period. Six selected combinations of different starter seed and wastewater, that is, CSsRBw, POsRBw, SMsPOw, RBsSWw, SWsCSw, and CSsSWw, were semicontinuously operated in larger reactor with stepwise increase of OLR $0.5-2.0 \mathrm{~kg} \mathrm{COD} / \mathrm{m}^{3} \cdot \mathrm{d}$ with $\mathrm{HRT}$ of 5 days. Figure 1 shows the biogas and methane production during start-up period in each combination. Only four combinations of different starter seed and wastewater, that is, RBsSMw, SMsPOw, SWsCSw, and CSsSWw, could achieve targeted OLR of $2.0 \mathrm{~kg} \mathrm{COD} / \mathrm{m}^{3} \cdot \mathrm{d}$ as shown in Table 4 , while CSsRBw treatment can only be operated at maximum OLR of $1.5 \mathrm{~kg} \mathrm{COD} / \mathrm{m}^{3} \cdot \mathrm{d}$ and POsRBw treatment was failed at step increasing to OLR $1.5 \mathrm{~kg} \mathrm{COD} / \mathrm{m}^{3} \cdot \mathrm{d}$, and however 
TABLE 3: Order of 25 factorial experiments based on rate and ultimate time of methane production.

\begin{tabular}{|c|c|c|c|c|}
\hline Number & Experiment & Ultimate $\mathrm{CH}_{4}$ production time (day) & $\begin{array}{l}\mathrm{CH}_{4} \text { production rate } \\
\left(\mathrm{mL} \mathrm{CH}_{4} / \mathrm{g} \text { VSS } \cdot \mathrm{d}\right)\end{array}$ & Lag time (days) \\
\hline 1 & $\mathrm{CSsRBw}^{*}$ & 7 & 12.37 & 0 \\
\hline 2 & SWsRBw & 8 & 8.32 & 0 \\
\hline 3 & POsRBw ${ }^{*}$ & 9 & 8.95 & 0 \\
\hline 4 & $\mathrm{SMsPOw}^{*}$ & 12 & 4.51 & 0 \\
\hline 5 & CSsPOw & 14 & 7.36 & 0 \\
\hline 6 & SMsRBw & 14 & 7.08 & 0 \\
\hline 7 & SMsSMw & 14 & 6.94 & 0 \\
\hline 8 & $\mathrm{CSsCSw}$ & 14 & 6.21 & 0 \\
\hline 9 & RBsRBw & 17 & 5.91 & 0 \\
\hline 10 & POsPOw & 17 & 4.77 & 0 \\
\hline 11 & POsCSw & 17 & 4.35 & 0 \\
\hline 12 & CSsSMw & 20 & 6.38 & 0 \\
\hline 13 & RBsPOw & 20 & 5.37 & 0 \\
\hline 14 & $\mathrm{RBsSMw}^{*}$ & 20 & 5.03 & 0 \\
\hline 15 & CSsSWw* & 20 & 3.37 & 0 \\
\hline 16 & SMsCSw & 22 & 4.78 & 6 \\
\hline 17 & POsCSw & 22 & 4.13 & 3 \\
\hline 18 & POsSWw & 22 & 2.38 & 0 \\
\hline 19 & $\mathrm{SWsCSw}^{*}$ & 24 & 3.86 & 0 \\
\hline 20 & SWsPOw & 24 & 3.74 & 0 \\
\hline 21 & SWsSMw & 24 & 2.69 & 0 \\
\hline 22 & $\mathrm{RBsCSw}$ & 30 & 3.92 & 4 \\
\hline 23 & RBsSWw & 30 & 3.01 & 0 \\
\hline 24 & SWsSWw & 30 & 2.65 & 0 \\
\hline 25 & SMsSWw & 32 & 1.71 & 0 \\
\hline
\end{tabular}

${ }^{*}$ Selected combinations of different starter seed and wastewater for next phase.

it can recover back to OLR of $1.0 \mathrm{~kg} \mathrm{COD} / \mathrm{m}^{3} \cdot \mathrm{d}$ until the end of operation. However various COD removals, methane yield, and production were observed in all reactor. Highest $\mathrm{CH}_{4}$ production and yield were observed in $\mathrm{SMsPOw}$ as $320 \mathrm{~mL} / \mathrm{d}$ and $160 \mathrm{~L} \mathrm{CH}_{4} / \mathrm{kg} \mathrm{COD}_{\text {added }}$, respectively, which were followed with those in RBsSMw, SWsCSw, and CSsSWw. The lowest $\mathrm{CH}_{4}$ production and yield were found at the combination of POsRBw as approximately $90 \mathrm{~mL} \mathrm{CH}_{4} / \mathrm{d}$ and $90 \mathrm{~L} \mathrm{CH}_{4} / \mathrm{kg} \mathrm{COD}_{\text {added }}$, respectively.

Based on the initial SMA results of starter seeds for these combinations, the activity of SWs, POs, and CSs was the higher compared to that of SMs and RBs as shown in Table 4, while rubber wastewater $(\mathrm{RBw})$ was the easiest degradable wastewater (based on ultimate methane production time) due to its high sCOD/tCOD ratio. However, the results of start-up operation for the combination between high active seeds and easy-degradable wastewater, such as POsRBw and CSsRBw, could not reach the targeted OLR of $2.0 \mathrm{~kg} \mathrm{COD} / \mathrm{m}^{3} \cdot \mathrm{d}$ and resulting poor performance in terms of COD removals, $\mathrm{CH}_{4}$ productions, and yields. On the contrary, high COD removals, $\mathrm{CH}_{4}$ productions, and yields were observed in SMsPOw and RBsSMw (combination between less active seeds and medium $\mathrm{sCOD/tCOD}$ ratio wastewater).
Food to microorganism (F/M) ratio applied in preliminary vial test and start-up of semicontinuous reactor were different. Fixed F/M ratio of 0.3 was used for vial test and stepwise F/M ratios from 0.5 to 2.0 were applied for start-up operation of semicontinuous reactor. As a result, easily degraded wastewater, such as RBw, was rapidly degraded by high active seeds which led to organic acids accumulation in reactor. This assumption was supported by TVA/alkalinity ratio in reactor of CSsRBw and POsRBw which were higher, approximately 0.4-0.6, compared to that in other combinations. The balance between acidogens and methanogens in these reactors may also affect their performances. It can be noticed from the result of Table 4. Moreover, the wastewater generated from concentrated rubber latex industry contains high organic, ammonia nitrogen, and sulfate concentrations. Ammonia in large amount is used as preservative agent for rubber latex and sulfuric acid is needed for recovering rubber particles in waste stream [18]. These high ammonia and sulfate adversely affect the microbial activity in anaerobic digestion system, especially methanogens as the most sensitive microorganism [19].

The specific glucose utilization, representative for activity of acidogens, in these reactors sharply increased, while the 


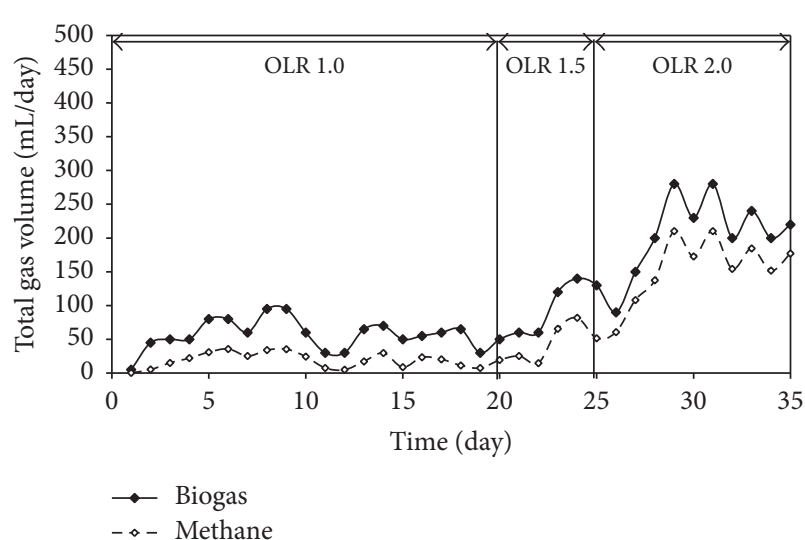

(a) $\mathrm{CSsSWw}$

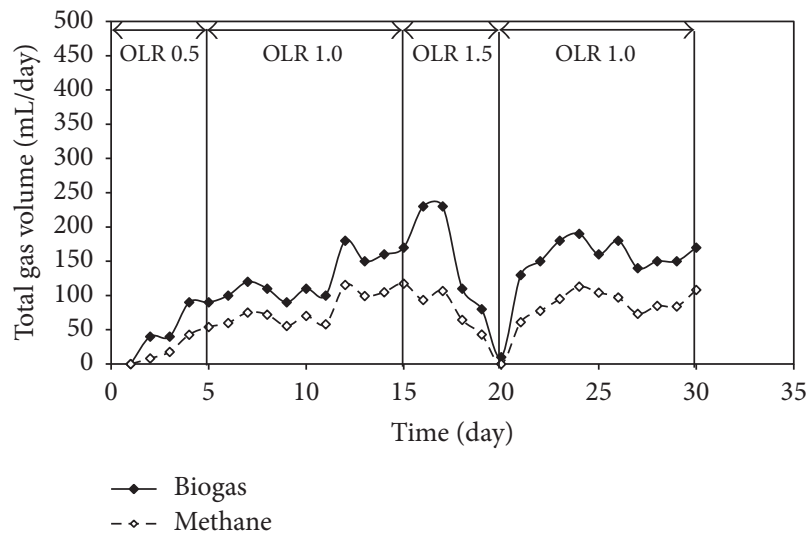

(c) POsRBw

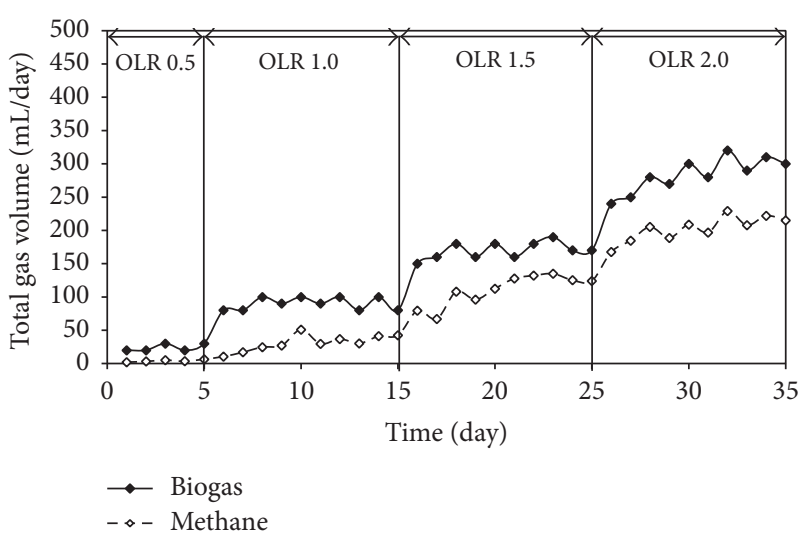

(e) RBsSMw

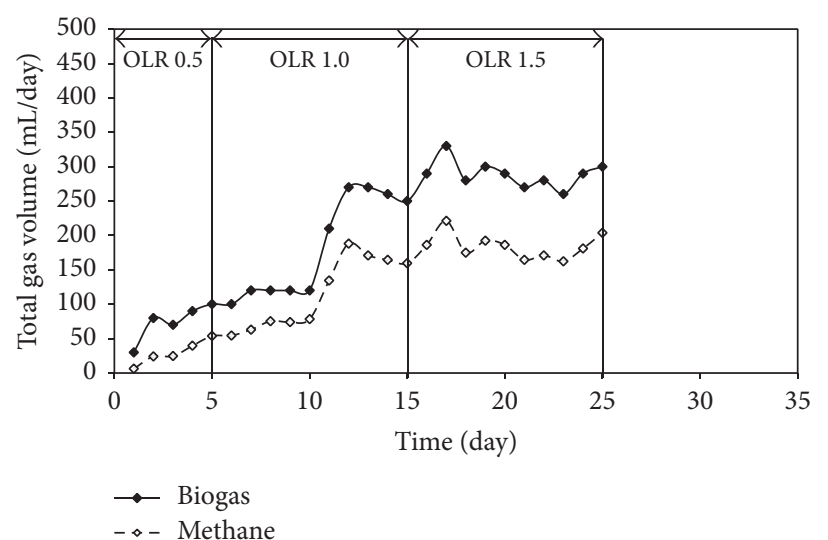

(b) $\mathrm{CSsRBw}$

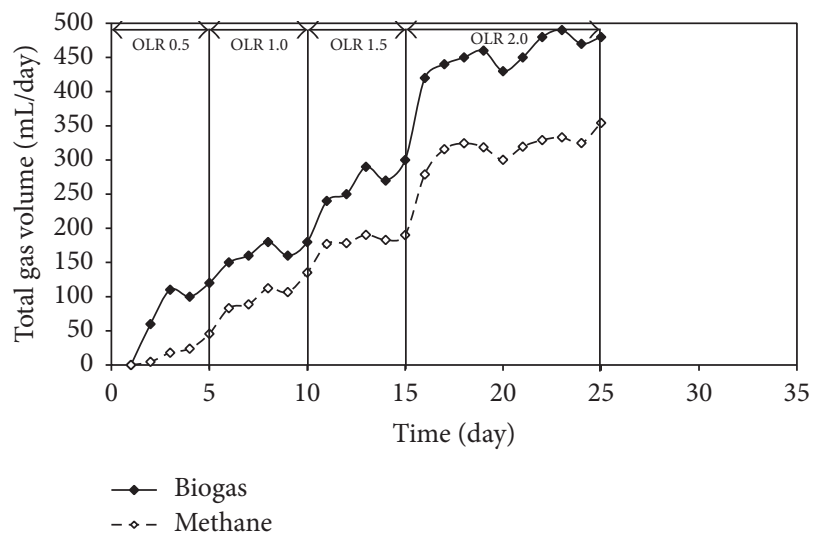

(d) SMsPOw

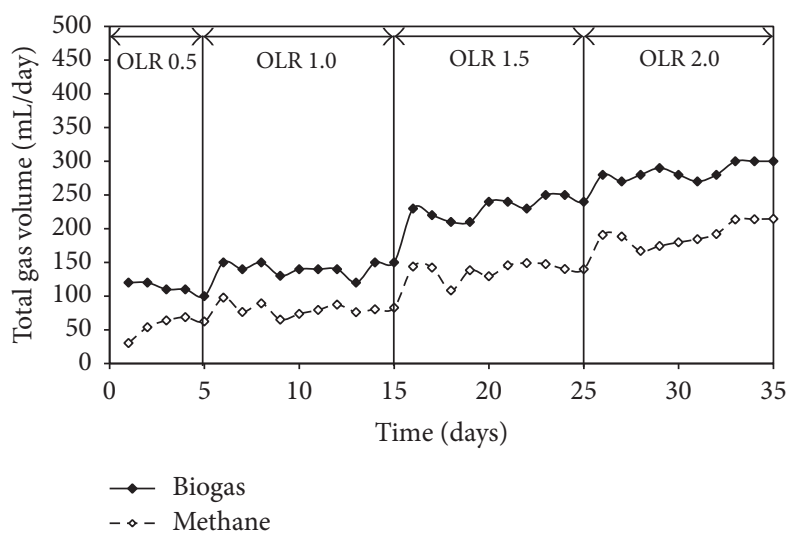

(f) $\mathrm{SWsCSw}$

FIGURE 1: Biogas and methane production of six conditions, CSsSWw (a), CSsRBw (b), POsRBw (c), SMsPOw (d), RBsSMw (e), and SWsCSw (f).

activity of acetoclastic methanogens (SMA) decreased as approximately 38,15 , and $36 \%$, respectively. High active acidogens could lead to fast acids production and low $\mathrm{pH}$ in the system which affected the activity of acetoclastic methanogens. However, glucose utilization in SMsPOw and RBsSMw was very low and the increase of activity of acetoclastic methanogens in these reactors was approximately 350 and $150 \%$, respectively. Organic acids from acidogenic activity were expected to be used directly by methanogens to produce methane which resulted in less acids accumulation and low TVA/alkalinity ratio inside reactors. From these results, it can be stated that the parameter of $\mathrm{F} / \mathrm{M}$ ratio, the characteristics of seeds, and wastewaters must be notably considered for reactor operation with combination of various starter seeds and wastewaters.

3.3. Microbial Community Based on DGGE Profiles. Tables 5 and 6 summarize the observed bands and their related 
TABLE 4: Performances of six selected combinations of different starter seed and wastewater.

\begin{tabular}{|c|c|c|c|c|c|c|}
\hline Parameter & CSsRBw & POsRBw & RBsSMw & SMsPOw & SWsCSw & CSsSWw \\
\hline $\begin{array}{l}\mathrm{SMA}_{\text {initial }} \text { (g } \\
\mathrm{COD}-\mathrm{CH}_{4} / \mathrm{g} \\
\text { VSS.d) }\end{array}$ & 0.13 & 0.11 & 0.02 & 0.06 & 0.08 & 0.13 \\
\hline $\begin{array}{l}\mathrm{SMA}_{\text {final }}(\mathrm{g} \\
\mathrm{COD} \mathrm{CH} \\
\mathrm{VSS} \cdot \mathrm{d}) \\
\end{array}$ & 0.11 & 0.07 & 0.09 & 0.12 & 0.09 & 0.08 \\
\hline $\begin{array}{l}\mathrm{SGU}_{\text {initial }}(\mathrm{g} \\
\mathrm{COD} / \mathrm{g} \text { VSS·h) }\end{array}$ & 0.26 & 0.29 & 0.18 & 0.38 & 0.38 & 0.26 \\
\hline $\begin{array}{l}\mathrm{SGU}_{\text {final }}(\mathrm{g} \\
\mathrm{COD} / \mathrm{g} \text { VSS·h) }\end{array}$ & 0.37 & 0.39 & 0.20 & 0.29 & 0.41 & 0.43 \\
\hline $\begin{array}{l}\text { Final OLR }(\mathrm{kg} \\
\left.\mathrm{COD} / \mathrm{m}^{3} \cdot \mathrm{d}\right)\end{array}$ & 1.5 & 1.0 (recovery) & 2.0 & 2.0 & 2.0 & 2.0 \\
\hline $\begin{array}{l}\text { TVA/alkalinity } \\
\text { ratio } \\
\end{array}$ & $0.4-0.6$ & $0.4-0.6$ & $0.3-0.5$ & $0.3-0.5$ & $0.5-0.6$ & $0.4-0.5$ \\
\hline $\begin{array}{l}\text { Av. sCOD } \\
\text { removal (\%) }\end{array}$ & 94 & 74 & 96 & 75 & 93 & 87 \\
\hline $\begin{array}{l}\text { Av. tCOD } \\
\text { removal (\%) }\end{array}$ & 85 & 55 & 76 & 57 & 79 & 67 \\
\hline $\begin{array}{l}\text { Av. biogas } \\
\text { production } \\
(\mathrm{mL} / \mathrm{d})\end{array}$ & 289 & 160 & 284 & 457 & 285 & 209 \\
\hline $\begin{array}{l}\text { Av. } \mathrm{CH}_{4} \\
\text { production } \\
(\mathrm{mL} / \mathrm{d})\end{array}$ & 185 & 90 & 203 & 320 & 192 & 157 \\
\hline $\begin{array}{l}\mathrm{CH}_{4} \text { yield }(\mathrm{L} / \mathrm{kg} \\
\left.\mathrm{COD}_{\text {added }}\right)\end{array}$ & 123 & 90 & 101 & 160 & 96 & 78 \\
\hline OLR achieved & $\begin{array}{l}\text { Not reach } \\
\text { OLR2, max. } \\
\text { OLR } 1.5\end{array}$ & $\begin{array}{l}\text { Fail at OLR 1.5, } \\
\text { at recovered } \\
\text { OLR } 1.0\end{array}$ & OLR 2 at day 35 & OLR 2 at day 25 & OLR 2 at day 35 & $\begin{array}{c}\text { OLR } 2 \text { at day } \\
35\end{array}$ \\
\hline
\end{tabular}

microorganism along with the percent of similarities for the bacterial and archaeal communities in initial seed starters and combination of between seed starters and wastewater at the end of start-up period. In anaerobic digestion, Eubacteria is distinguished into three main groups, namely, hydrolytic, acidogenic, and acetogenic groups. Those three main microbial groups were observed in all initial starter seeds with different dominant microorganism. Starter seed from swine manure WWTP consisted of the most Eubacteria compared to other starter seeds. 4 out of 5 hydrolytic, 3 out of 5 acidogenic, and 5 out of 8 acetogenic microorganisms were detected from SWs, while RBs showed the least detected bacteria (2 out of 5 hydrolytic, 1 out of 5 acidogenic, and 2 out of 8 acetogenic bacteria).

Acetogenic bacteria have important role for oxidizing products from acidogenesis and providing appropriate substrate for methanogens. Therefore, acetogens $\left(\mathrm{H}_{2}\right.$ producers) syntrophically collaborate with methanogens $\left(\mathrm{H}_{2}\right.$ consumers) [5]. 5 dominant bands of acetogens were detected in SWs, more than other starter seeds. Syntrophus sp. and Smithella propionica strain LYP were observed in all starter seeds. These microorganisms were considered as acetogens in which Smithella propionica strain LYP utilized propionate to produce acetate and hydrogen and Syntrophus sp. syntrophically cooperate with hydrogenotrophic methanogens [20,
21]. Several sulfate reducing bacteria, such as Sulfuricurvum kujiense strain DSM 16994, Syntrophus gentianae strain HQgoel, Desulfococcus biacutus, and Shewanella amazonensis, and one of nitrate reducing bacteria (Nitratiruptor sp.) were also detected in SWs. These dominant bacteria found in SWs were affected by the characteristics of swine manure wastewater which contained high protein, carbohydrate, lipid, and total nitrogen as shown in Table 1. High SRB found in SWs was probably caused by high sulfur concentration in swine manure wastewater $[22,23]$.

Eubacteria in the combination between starter seeds and wastewaters during start-up period were also investigated (Figure 2 and Table 5). The combination of SMsPOw, RBsSMw, and SWsCSw, which showed good performance until OLR $2.0 \mathrm{~kg} \mathrm{COD} / \mathrm{m}^{3} \cdot \mathrm{d}$, has few bacteria. Two hydrolytic, three acidogenic, and one acetogenic microorganism were detected in the highest performance combination of SMsPOw, while combination of POsRBw, the lowest performance, has 8 dominant bacteria as 2 bacteria of each hydrolytic, acidogenic, and acetogenic microorganism and SRB. Arcobacter cryaerophilus strain A 169/B (band 12) and Sunxiuqinia faeciviva strain JAM-BA0302 (band 5) were detected in all samples as carbohydrate- and proteindegrading microorganism, respectively [24, 25]. More protein-degrading microorganism, Polaribacter porphyrae 


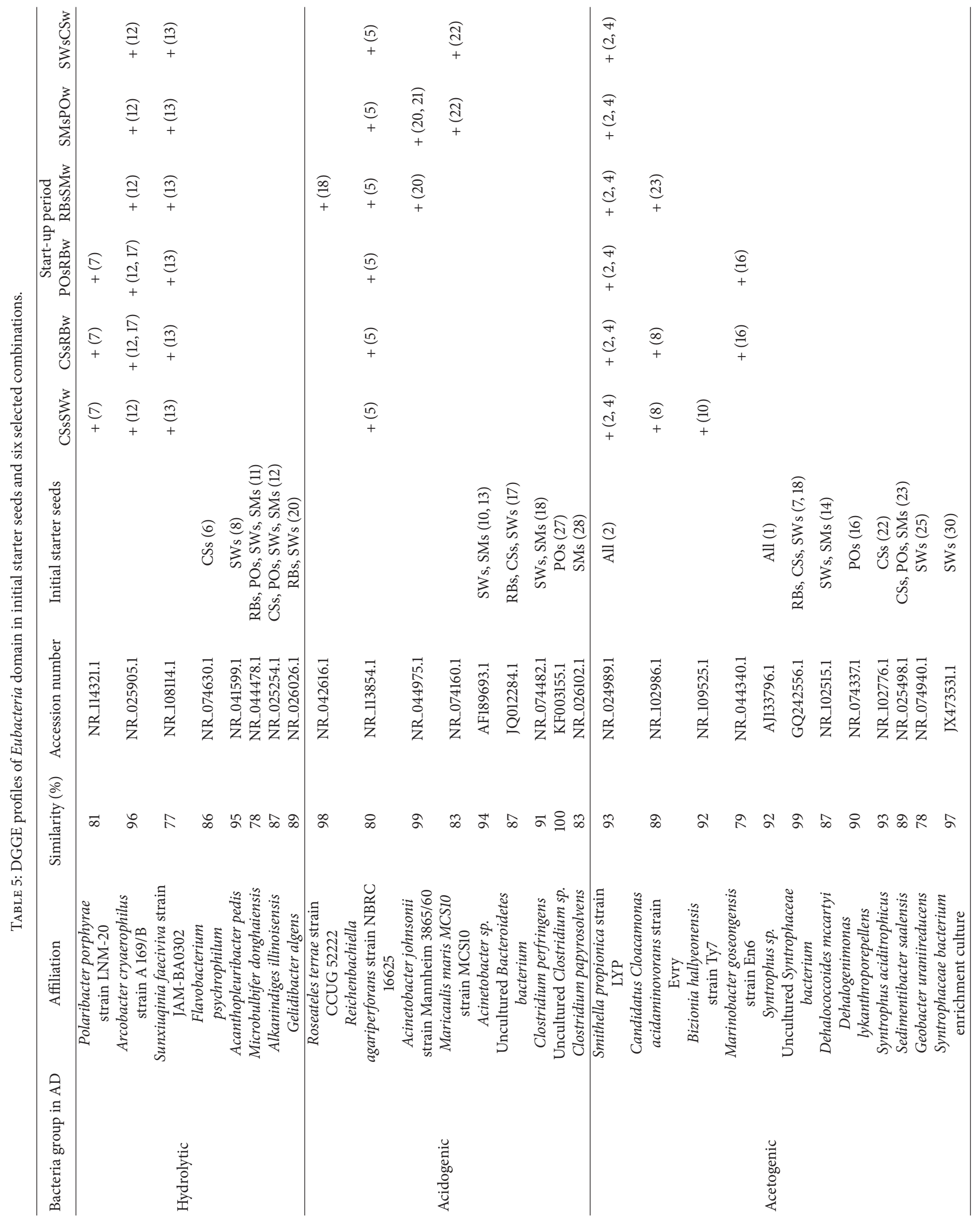




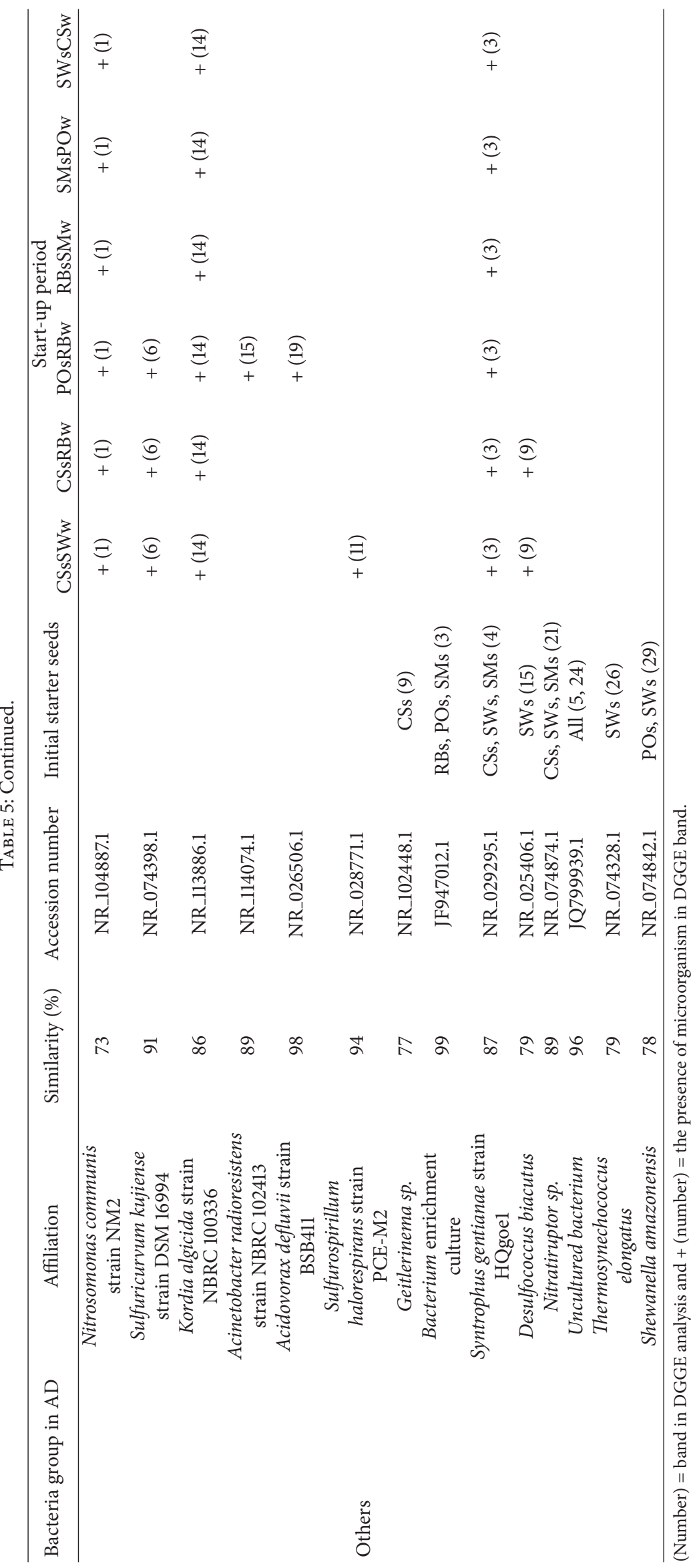



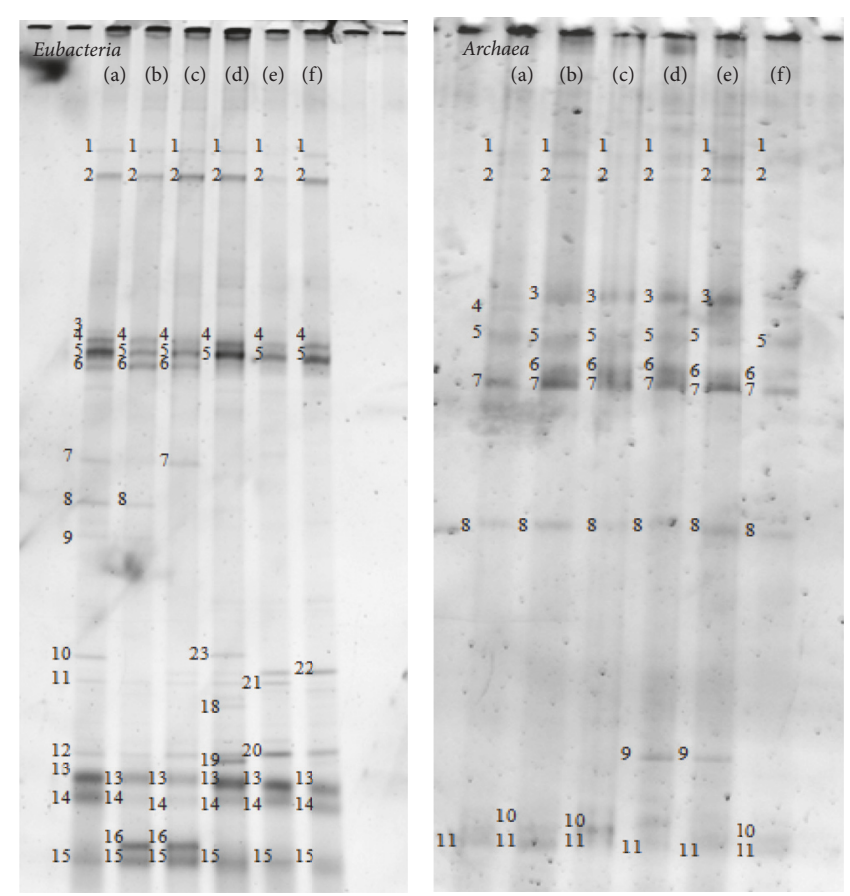

Figure 2: DGGE pattern of Eubacteria and Archaea groups from various combinations, CSsSWw (a), CSsRBw (b), POsRBw (c), RBsSMw (d), SMsPOw (e), and SWsCSw (f).

strain LNM-20 (band 7), was detected in combination of CSsSWw, CSsRBw, and POsRBw. Protein concentration in wastewaters of SWw and RBw was higher compared to other wastewaters, as approximately 40.47 and $10.98 \mathrm{~g} / \mathrm{L}$, respectively. It is clear that wastewaters may contain their indigenous microorganism. Acetogenic (amino acid degrader), Candidatus Cloacamonas acidaminovorans strain Evry (band 8), was also detected in combinations of CSsSWw and CSsRBw. More SRB also detected in combination starter seeds with swine manure wastewater.

Three main groups of methanogens, namely, methylotrophic, hydrogenotrophic, and acetoclastic methanogens, were observed at both sample conditions as shown in Table 6. Methanomethylovorans hollandica strain DSM 15978 was detected at band 8 (initial starter seed) and band 7 (combination during start-up) in all samples. This microorganism is isolated from freshwater sediment and obligately methylotrophic methanogen since it utilizes only methanol, methylamines, methanethiol, and dimethyl sulfide [26]. Another methylotrophic methanogen, Methanosarcina acetivorans strain $\mathrm{C} 2 \mathrm{~A}$, was observed as band 3 in some combination treatment (CSsRBw, POsRBw, RBsSMw, and $\mathrm{SMsPOw}$ ). Carbon monoxide is utilized by this microorganism to produce methane via a pathway that involves $\mathrm{H}_{2}$ as an intermediate [27]. Three hydrogenotrophic methanogens were observed in combination treatments such as Methanolinea mesophila strain TNR (band 4 in CSsSWw), Methanolinea tarda strain NOBI-1 (band 5 in all samples), and Methanoregula formicica strain SMSP (band 6 in CSsRBw, POsRBw, RBsSMw, SMsPOw, and SWsCSw), while only one hydrogenotrophic methanogen (Methanoregula formicica strain SMSP) was detected in initial starter seeds of CSs and SWs as band 9. These hydrogenotrophic methanogens are mesophilic and utilize $\mathrm{H}_{2} / \mathrm{CO}_{2}$ and formate to produce methane [28-30]. Methanosaeta concilii GP6, an acetoclastic methanogen, was detected in all initial starter seeds (band 2) and in all combination treatments (bands 1, 2, 8, and 11). Methanosarcina mazei Gol was only detected in combination treatments of CSsRBw and POsRBw at band 10. Another acetoclastic methanogens, that is, Methanosaeta harundinacea, was only detected in initial all starter seeds. This microorganism only grows in very high acetate concentration ( $>100 \mathrm{mM})$ as exclusive substrate [31]. It can be assumed that the absence of this microorganism in combination treatment was probably caused by low acetate production during start-up period of this treatment. Acetoclastic methanogens, that is, Methanosarcina and Methanosaeta, contribute approximately two-thirds of methane production from acetate. Methanosaeta spp. are widely distributed in natural environment and their filamentous cell trigger sludge granulation [31]. Another uncultured Archaea were also detected in initial seed starters as shown in Table 6. It seems that wastewaters used as combination treatment may contain its indigenous archaeal microorganism since more methanogens were detected at this sample.

\section{Conclusions}

The efficacies of exogenous starter seeds to treat different wastewater were investigated in this study. All of exogenous anaerobic starter seeds were able to produce $\mathrm{CH}_{4}$ from 


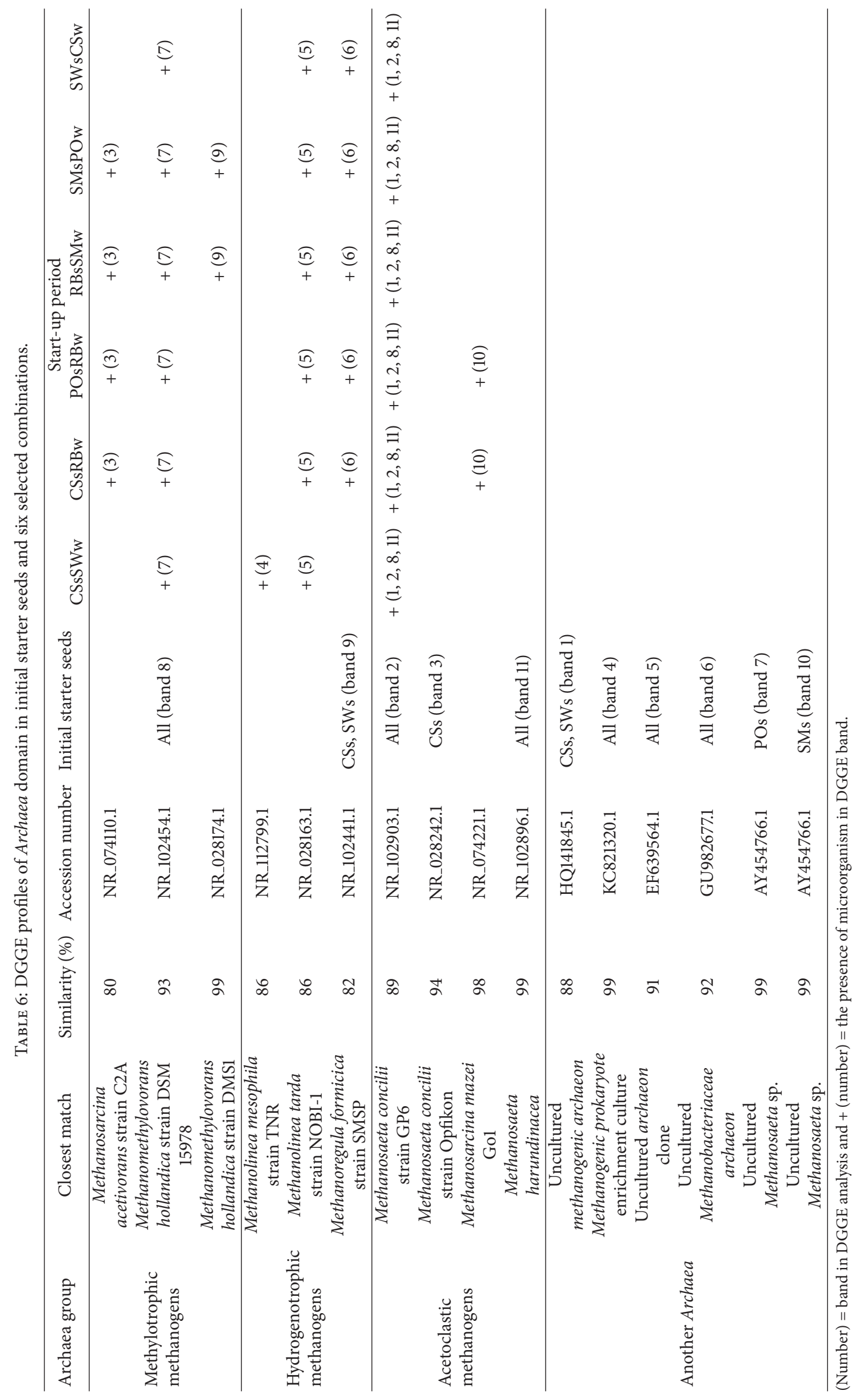


different sources of wastewater, although the different $\mathrm{CH}_{4}$ production rates and lag phases were observed. The effectiveness of using different exogenous anaerobic starter seeds to treat different wastewater types was not only determined by the quality of starter seeds and wastewaters but also considered by the F/M ratio and microbial community inside starter seeds. It was shown by the results above in which the combination between high active starter seeds and easy-degradable wastewaters (high sCOD/tCOD ratio), such as CSsRBw and POsRBw, could not achieve the targeted OLR of $2 \mathrm{~kg} \mathrm{COD} / \mathrm{m}^{3} \cdot \mathrm{d}$. On the contrary, less active starter seeds with medium-degradable wastewater, such as $\mathrm{RBsSMw}$ and SMsPOw, showed good performances until reaching the targeted OLR. Therefore, it can be assumed that $\mathrm{F} / \mathrm{M}$ ratio affected these results via microbial community and their microbial activities. High F/M ratio with easydegradable wastewater initiated fast microbial degradation (higher SGU) which led to acids accumulation in reactor and decreased methanogens activity (lower SMA). As such, this $\mathrm{F} / \mathrm{M}$ parameter needs to be considered for starting up new anaerobic reactor with exogenous starter seeds and easydegradable wastewaters. Based on DGGE profiles, Smithella propionica strain LYP and Syntrophus sp. were detected in all of initial starter seeds and selected combinations of different starter seeds and wastewaters. For Archaea domain, methylotrophic, hydrogenotrophic, and acetoclastic methanogen were detected in all samples which were represented by Methanomethylovorans hollandica strain DMS1, Methanoregula formicica strain SMSP, and Methanosaeta concilii strain GP6, respectively. Propionate utilizer (Smithella propionica strain LYP) was assumed to produce acetate and hydrogen for those methanogens under syntrophic relationship.

\section{Conflicts of Interest}

The authors declare that there are no conflicts of interest regarding the publication of this paper.

\section{Acknowledgments}

This research was funded by National Research Council of Thailand (NRCT: WUM-BG-RD-57-05) and facilitated by Excellent Center of Waste Utilization and Management (ECoWaste) and the Joint Graduate School of Energy and Environment (JGSEE), King Mongkut's University of Technology Thonburi.

\section{References}

[1] J. B. van Lier, F. P. van der Zee, C. T. M. J. Frijters, and M. E. Ersahin, "Celebrating 40 years anaerobic sludge bed reactors for industrial wastewater treatment," Reviews in Environmental Science and Biotechnology, vol. 14, no. 4, pp. 681-702, 2015.

[2] T. J. Britz, C. Lamprecht, and G. O. Sigge, "Dealing with Environmental Issues," in Advanced Dairy Science and Technology, T. J. Britz and and R. K. Robinson, Eds., pp. 262-293, Blackwell, Oxford, UK, 2008.

[3] P. Chaiprasert, "Biogas production from agricultural wastes in Thailand, Journal of Sustainable Energy Environment," Special Issue, pp. 63-65, 2011.
[4] M. E. Griffin, K. D. McMahon, R. I. Mackie, and L. Raskin, "Methanogenic population dynamics during start-up of anaerobic digesters treating municipal solid waste and biosolids," Biotechnology and Bioengineering, vol. 57, no. 3, pp. 342-355, 1998.

[5] C. A. d. L. Chernicharo, "Anaerobic reactors," in Biological Wastewater Treatment Series, IWA Publishing, London, UK, 2007.

[6] F. Ali Shah, Q. Mahmood, M. M. Shah, A. Pervez, and S. A. Asad, "Microbial ecology of anaerobic digesters: the key players of anaerobiosis," The Scientific World Journal, vol. 2014, Article ID 183752, 21 pages, 2014.

[7] N. A. Oz, O. Ince, G. Turker, and B. K. Ince, "Effect of seed sludge microbial community and activity on the performance of anaerobic reactors during the start-up period," World Journal of Microbiology and Biotechnology, vol. 28, no. 2, pp. 637-647, 2012.

[8] N. Hudayah, B. Suraraksa, and P. Chaiprasert, "Synergistic effects of the chitosan addition and polysaccharides-EPS on the formation of anaerobic granules," Environmental Technology (United Kingdom), vol. 37, no. 21, pp. 2713-2722, 2016.

[9] A. P. H. A. Standard, method for the examination of water and wastewater, American Public Health Association, Washington, DC, USA, 2005.

[10] G. Yadang, J. B. Tchatcheung, and C. Tchiegang, "Protein Carbohydrate, Fat and Energy Content of, Ready-to-Eat Foods , in Cameroonian Sahels Region," Journal of Food Technology, vol. 7, no. 1, p. 4, 2009.

[11] G. L. Miller, "Use of dinitrosalicylic acid reagent for determination of reducing sugar," Analytical Chemistry, vol. 31, no. 3, pp. 426-428, 1959.

[12] M. Soto, R. Méndez, and J. M. Lema, "Methanogenic and nonmethanogenic activity tests. Theoretical basis and experimental set up," Water Research, vol. 27, no. 8, pp. 1361-1376, 1993.

[13] J. Zhou, M. A. Bruns, and J. M. Tiedje, "DNA recovery from soils of diverse composition," Applied and Environmental Microbiology, vol. 62, no. 2, pp. 316-322, 1996.

[14] R. I. Amann, W. Ludwig, and K.-. Schleifer, "Phylogenetic identification and in situ detection of individual microbial cells without cultivation," Microbiological Reviews, vol. 59, no. 1, pp. 143-169, 1995.

[15] L. Raskin, L. K. Poulsen, D. R. Noguera, B. E. Rittmann, and D. A. Stahl, "Quantification of methanogenic groups in anaerobic biological reactors by oligonucleotide probe hybridization," Applied and Environmental Microbiology, vol. 60, no. 4, pp. 12411248, 1994.

[16] T. Shigematsu, Y. Tang, Y. Mizuno, H. Kawaguchi, S. Morimura, and K. Kida, "Microbial diversity of mesophilic methanogenic consortium that can degrade long-chain fatty acids in chemostat cultivation," Journal of Bioscience and Bioengineering, vol. 102, no. 6, pp. 535-544, 2006.

[17] S. F. Altschul, W. Gish, W. Miller, E. W. Myers, and D. J. Lipman, "Basic local alignment search tool," Journal of Molecular Biology, vol. 215, no. 3, pp. 403-410, 1990.

[18] K. Saritpongteeraka and S. Chaiprapat, "Effects of pH adjustment by parawood ash and effluent recycle ratio on the performance of anaerobic baffled reactors treating high sulfate wastewater," Bioresource Technology, vol. 99, no. 18, pp. 89878994, 2008.

[19] Q.-I. Zhao, W. Li, and S.-J. You, "Simultaneous removal of ammonium-nitrogen and sulphate from wastewaters with an 
anaerobic attached-growth bioreactor," Water Science and Technology, vol. 54, no. 8, pp. 27-35, 2006.

[20] Y. Liu, D. L. Balkwill, H. C. Aldrich, G. R. Drake, and D. R. Boone, "Characterization of the anaerobic propionatedegrading syntrophs Smithella propionica gen. nov., sp. nov. and Syntrophobacter wolinii," in Proceedings of the International Journal of Systematic Bacteriology, vol. 49, pp. 545-556, 1999.

[21] B. Schink and A. J. M. Stams, "Syntrophism among prokaryotes," The Prokaryotes, vol. 2, pp. 309-335, 2006.

[22] S. Tuesorn, S. Wongwilaiwalin, V. Champreda et al., "Enhancement of biogas production from swine manure by a lignocellulolytic microbial consortium," Bioresource Technology, vol. 144, pp. 579-586, 2013.

[23] T. F. Ducey and P. G. Hunt, "Microbial community analysis of swine wastewater anaerobic lagoons bynext-generation DNA sequencing," Anaerobe, vol. 21, pp. 50-57, 2013.

[24] K. Takai, M. Abe, M. Miyazaki et al., "Sunxiuqinia faeciviva sp. nov., a facultatively anaerobic organoheterotroph of the Bacteroidetes isolated from deep subseafloor sediment," in Proceedings of the International Journal of Systematic and Evolutionary Microbiology, vol. 63, pp. 1602-1609.

[25] W. Whitman, M. Goodfellow, P. Kämpfer et al., Bergey's Manual of Systematic Bacteriology, Springer, New York, NY, USA, 2012.

[26] B. P. Lomans, R. Maas, R. Luderer et al., "Isolation and characterization of Methanomethylovorans hollandica gen. nov., sp. nov., isolated from freshwater sediment, a methylotrophic methanogen able to grow on dimethyl sulfide and methanethiol," Applied and Environmental Microbiology, vol. 65, no. 8, pp. 3641-3650, 1999.

[27] M. Rother and W. W. Metcalf, "Anaerobic growth of Methanosarcina acetivorans C2A on carbon monoxide: an unusual way of life for a methanogenic archaeon," Proceedings of the National Academy of Sciences of the United States of America, vol. 101, no. 48, pp. 16929-16934, 2004.

[28] S. Sakai, M. Ehara, I.-C. Tseng et al., "Methanolinea mesophila sp. nov., a hydrogenotrophic methanogen isolated from rice field soil, and proposal of the archaeal family Methanoregulaceae fam. nov. within the order Methanomicrobiales," International Journal of Systematic and Evolutionary Microbiology, vol. 62, no. 6, pp. 1389-1395, 2012.

[29] H. Imachi, S. Sakai, Y. Sekiguchi et al., "Methanolinea tarda gen. nov., sp. nov. a methane-producing archaeon isolated from a methanogenic digester sludge," International Journal of Systematic and Evolutionary Microbiology, vol. 58, no. 1, pp. 294301, 2008 .

[30] Y. Yashiro, S. Sakai, M. Ehara, M. Miyazaki, T. Yamaguchi, and H. Imachi, "Methanoregula formicica sp. nov., a methaneproducing archaeon isolated from methanogenic sludge," International Journal of Systematic and Evolutionary Microbiology, vol. 61, no. 1, pp. 53-59, 2011.

[31] L. Zhou, H. Yu, G. Ai, B. Zhang, S. Hu, and X. Dong, "Transcriptomic and physiological insights into the robustness of long filamentous cells of Methanosaeta harundinacea, prevalent in upflow anaerobic sludge blanket granules," Applied and Environmental Microbiology, vol. 81, no. 3, pp. 831-839, 2015. 

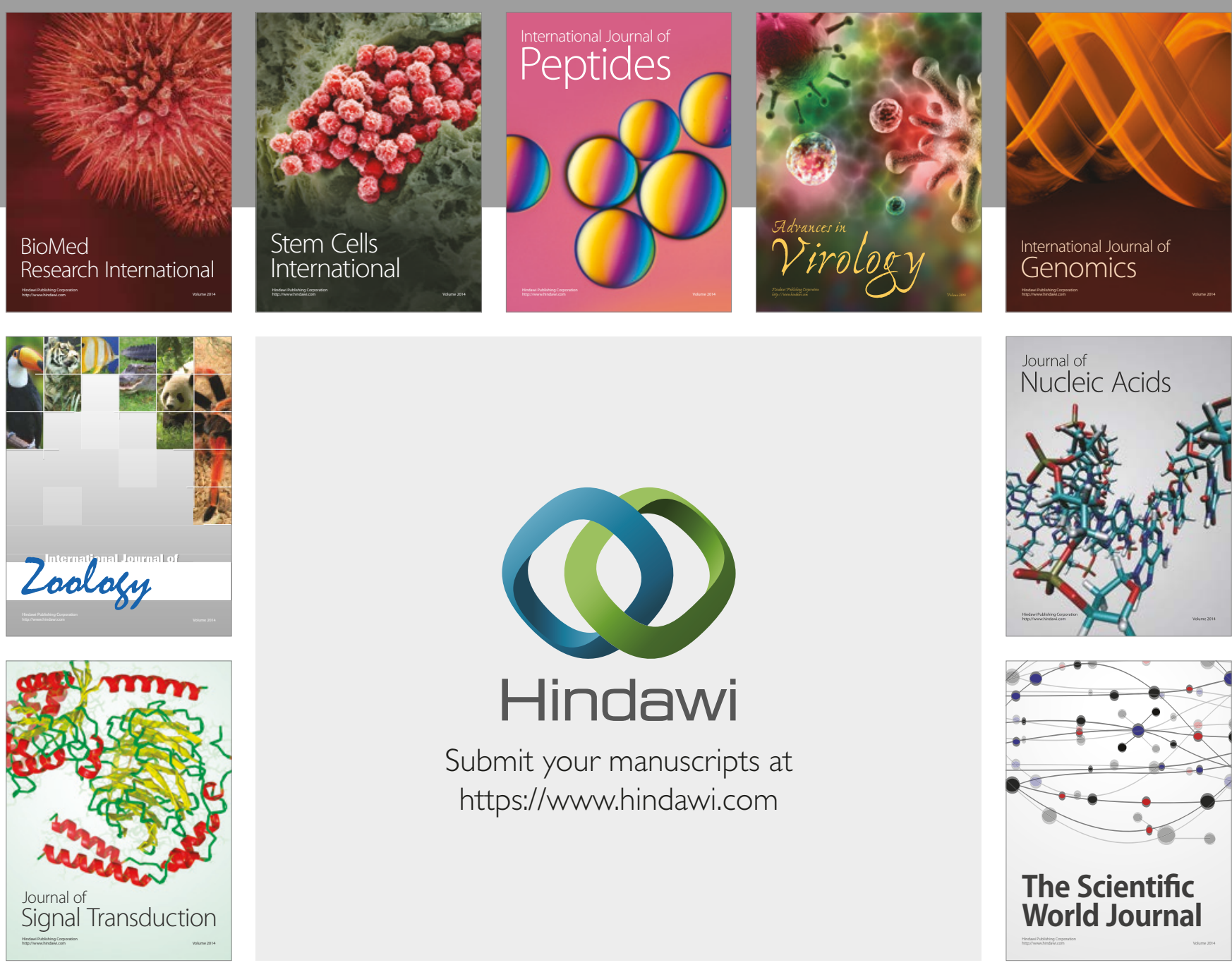

Submit your manuscripts at

https://www.hindawi.com
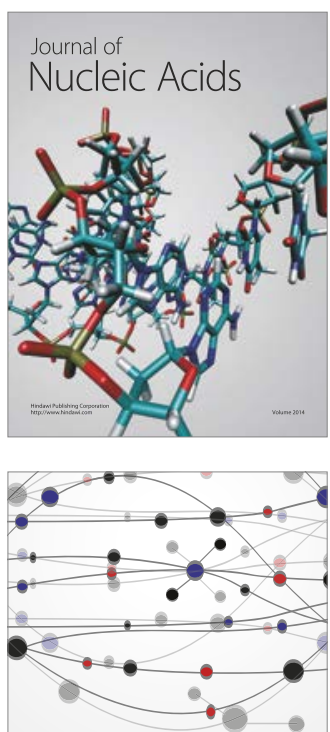

The Scientific World Journal

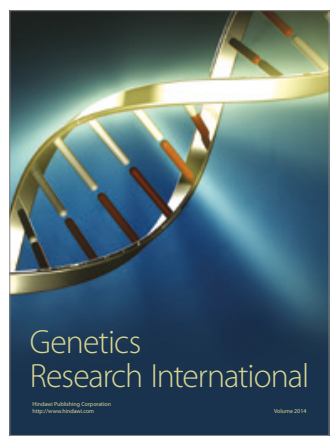

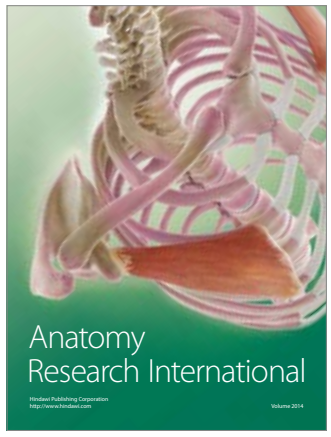

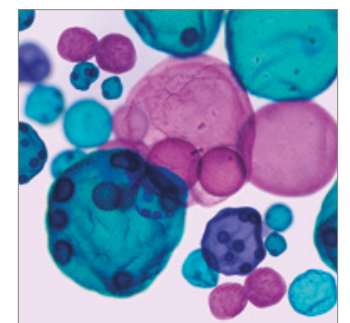

International Journal of Microbiology
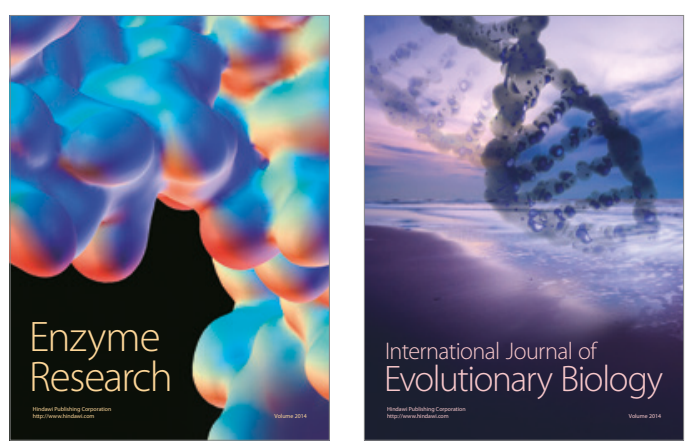
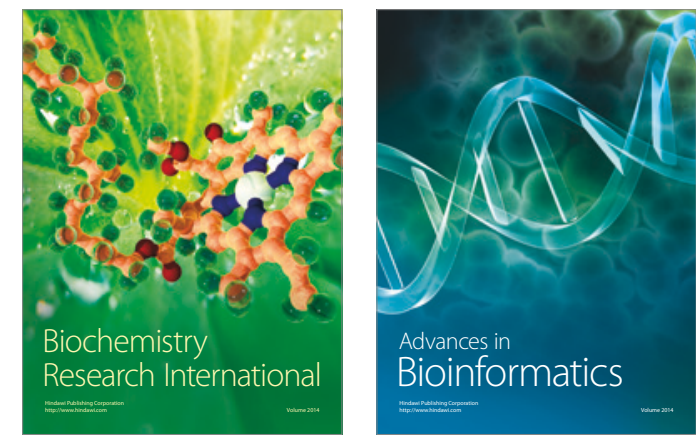

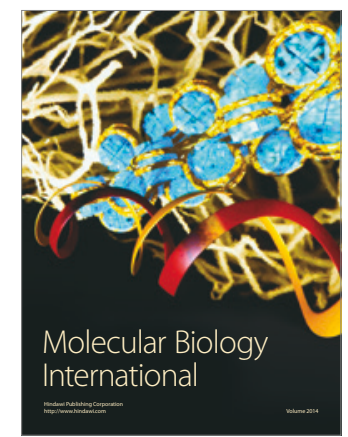

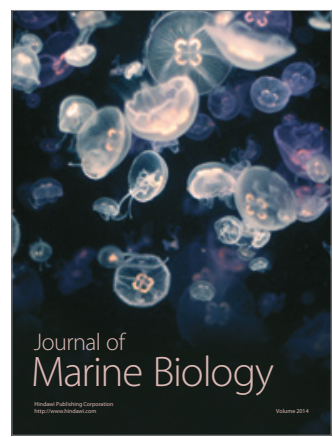

